\title{
AN EARLY ACCOUNT OF RHEUMATIC HEART DISEASE BY JOSEPH BROWN (1784-1868)
}

\author{
by \\ D. EVAN BEDFORD, WILLIAM HARTSTON AND SIR ROBERT DREW*
}

KNOWLEDGe of rheumatic heart disease dates back to 1788 when David Pitcairn spoke of it at St. Bartholomew's Hospital and much has been written on the subject since. However, Joseph Brown's Medical essays of $1828^{1}$ seems to have been overlooked as there is no mention of it either in Herrick's History of cardiology $y^{2}$ or in Parkinson's Harveian Oration on 'Rheumatic fever and heart disease' which includes a comprehensive bibliography. ${ }^{3}$ At first pericarditis was the only disease of the heart ascribed to acute rheumatism, next cardiac enlargement was added and finally Bouillaud is generally credited with the first recognition of endocarditis in $1835 .^{4,5}$

Joseph Brown's book emphasizing the dominant role of rheumatism in the causation of endocarditis and valvular disease, was published seven years before Bouillaud's treatise and before the first edition of Hope's book. ${ }^{6}$ It is rewarding to look into the career of this remarkable army surgeon and to review his contribution to cardiology.

\section{BIOGRAPHICAL NOTE}

Joseph Brown was born in North Shields, Northumberland, in 1784, the seventh son of Mr. George Brown, a member of the Society of Friends. He studied medicine in Edinburgh and London and, in spite of his Quaker upbringing, entered in 1808 the Army Medical Service as assistant surgeon. He served with distinction in Wellington's army (1810-1813) in the Peninsular War ${ }^{7}$ and was present at the battles of Busaco, Albuhera, Vittoria, the Pyrenees and Nivelle, being awarded the silver medal with five clasps. In this war three times as many deaths resulted from disease, including dysentery, malaria, typhus and tetanus, as from wounds. Tetanus was mentioned as having 100 per cent mortality, though Brown was reported to have treated two cases successfully by "antiphlogistic" measures and emollients to the wounds.

He was also credited with advising the addition of butter, cheese and bacon to the soldiers' rations. It seems likely therefore that his duties were medical rather than surgical. After the battle of Waterloo he served with the army of occupation until 1819 when he retired on half pay, obtained the degree of M.D. Edinburgh with a thesis de morbis venereis, and married the widow of Lt. Elwes, who had been killed at Waterloo. After this he settled in Sunderland, where he was appointed to the staff

*D. Evan Bedford, C.B.E., M.D., F.R.C.P., 118 St. Pancras, Chichester, Sussex.

William Hartston, M.D., F.R.C.P., D.T.M., Chest Department, St. Thomas's Hospital, London S.E.1. Lt.-Gen. Sir Robert Drew, K.C.B., C.B.E., F.R.C.P., British Postgraduate Medical Federation, 14 Milman Mews, London W.C.1. 


\section{Short Articles}

of the new Infirmary in 1822. He built up a large practice which extended into the surrounding area where consultations often took him on horseback to Darlington, Barnard Castle and even as far afield as York in the days before rail travel. In 1824 he was admitted an extra licentiate of the Royal College of Physicians of London and a brief biography is given in Munk's Roll. ${ }^{8}$ Brown was accepted as an authority on fever, cholera, plague and sanitary science, on which subjects he was the selected contributor to Sir John Forbes's four-volume Cyclopaedia of practical medicine (1835) and to the British and Foreign Quarterly Medical Review.

He took an active part in local politics as a borough magistrate and in 1840 was elected Mayor of Sunderland. He did much to improve the housing conditions of the poor and in appreciation of his efforts on their behalf the people of the town in 1858 presented him with a testimonial of $£ 1,000$. When chairman of the medical board of the Infirmary in 1865, his portrait was hung alongside a marble bust (Fig.1) in the town's Subscription Library, of which he was president up to the time of his death from pneumonia in 1868, aged eighty-four.

\section{BROWN'S CONTRIBUTION TO CARDIOLOGY}

Perusal of his Medical essays shows that Brown was using the stethoscope regularly at Sunderland, and it seems likely that he had acquired one in France before returning to England in 1819. He evidently attended many necropsies on cardiac patients and kept careful records of his clinical and pathological findings, some of which are cited in detail and trace the course from the attack of rheumatic fever to the onset of congestive failure with complete arrhythmia. Three of the essays are devoted to heart disease; essay 4 deals with rheumatism, essay 5 with disease of the heart and its investing membrane, and essay 6 with sympathetic disorders of the heart.

He estimated that half of all cases of heart disease could be attributed to rheumatism and stated that "now when called to a case of affection of the heart my first enquiry is whether the patient has been subject to rheumatism". Unlike Bouillaud, he was cautious of bleeding and advocated moderate "antiphlogistic" treatment combined if necessary with Dover's powder or opium, calomel and James's antimonial powder. He noted that rheumatic heart disease occurred mainly in the labouring classes, though those in more affluent circumstances were by no means exempt. In reviewing current opinion on the causes of heart disease, such as excessive exertion, alcoholism, etc., he suggested that these were often combined with rheumatism and discussed the process of "metastasis" from the joints to the heart.

Essay 5 deals in turn with pericarditis, hypertrophy and dilatation, and finally with disease of the lining membrane and valves of the heart. His account of pericarditis is good and he described the characteristic posture in pericardial effusion, later known as the "pillow sign of Blechmann". The section on hypertrophy and dilatation, based on the ideas of Corvisart and Laënnec, is prolix, but from personal observations he recognized the large forcible heart with full pulse which today would suggest hypertension or aortic incompetence, and with small pulse which nowadays indicates aortic stenosis. In discussing angina pectoris he concluded that ossification of the coronary arteries was not always the exciting cause, though he had usually found it present in cardiac patients dying suddenly and unexpectedly. 


\section{Short Articles}

In his account of disease of the lining membrane and valves of the heart, he remarked that Bertin in his treatise edited by Bouillaud overlooked the rheumatic aetiology of endocarditis and certainly there is no mention of rheumatism in Bertin's treatise of 1824. ${ }^{\circ}$ Laënnec's error in attributing the second sound to atrial systole led to much confusion in the interpretation of murmurs, but to question his authority in respect of auscultation amounted almost to heresy.

Nevertheless controversy soon arose over the interpretation of heart sounds and murmurs and continued more or less throughout the century. Brown concluded that the bruit de soufflet was inherent in contraction of the left auricle in mitral disease and of the left ventricle in aortic disease but he remarked that it was also common when the heart was sound. The distinction between functional and organic murmurs has continued to trouble physicians in wartime and Parkinson has related his experience of this difficulty in the two European wars. ${ }^{10}$

Bouillaud in his treatise and in his Nouvelles recherches sur le rheumatisme articulaire aigu (1836) undoubtedly convinced the medical world of the rheumatic aetiology of endocarditis though his treatment by wholesale blood-letting soon fell into disrepute. Brown's account of rheumatic endocarditis, published seven years before Bouillaud's treatise, was not by any means based on casual observations but coming from an English provincial physician they failed to receive due recognition at a time when Paris was still the centre of progress in cardiology. In retrospect Brown may certainly be regarded as the pioneer exponent of the rheumatic aetiology of endocarditis and valvular disease of the heart. Like Bouillaud, he was not in any sense a narrow specialist for he wrote on a variety of medical subjects and contributed to general literature on topics such as diet and religion.

His obituary notices published in the Sunderland Herald and the Medical Times and Gazette ${ }^{11}$ described him as a classical scholar and highly educated man who never wearied of doing good for the poor. It is remarked that if the incidents of his career could be fully told they would furnish a narrative of more than ordinary interest, but materials for a full history of his life were never obtained owing to his reticence in talking about himself which discouraged potential biographers.

An insight into his deep moral and religious convictions and his qualities as political commentator and historiographer, is manifest in his book Memories of the past and thoughts on the present age. ${ }^{12}$ In this work, published five years before his death, he wrote "I am approaching my eightieth year, I can still observe, still reason on what I observe and the faculty of memory being left to me quite unimpaired." In simple clear impressive language he describes his military experiences. "I was literally present at the fall of the mighty Empire of Napoleon; almost literally I saw the iron army of France rent asunder when in April 1814 the British Army marched into Toulouse."

\section{ACKNOWLEDGEMENTS}

We wish to thank Mr. E. W. Kirtley, Assistant Director, Sunderland Museum and Libraries, for much help in compiling the biography of Brown and for the bas-relief which he photographed and permits us to reproduce. 


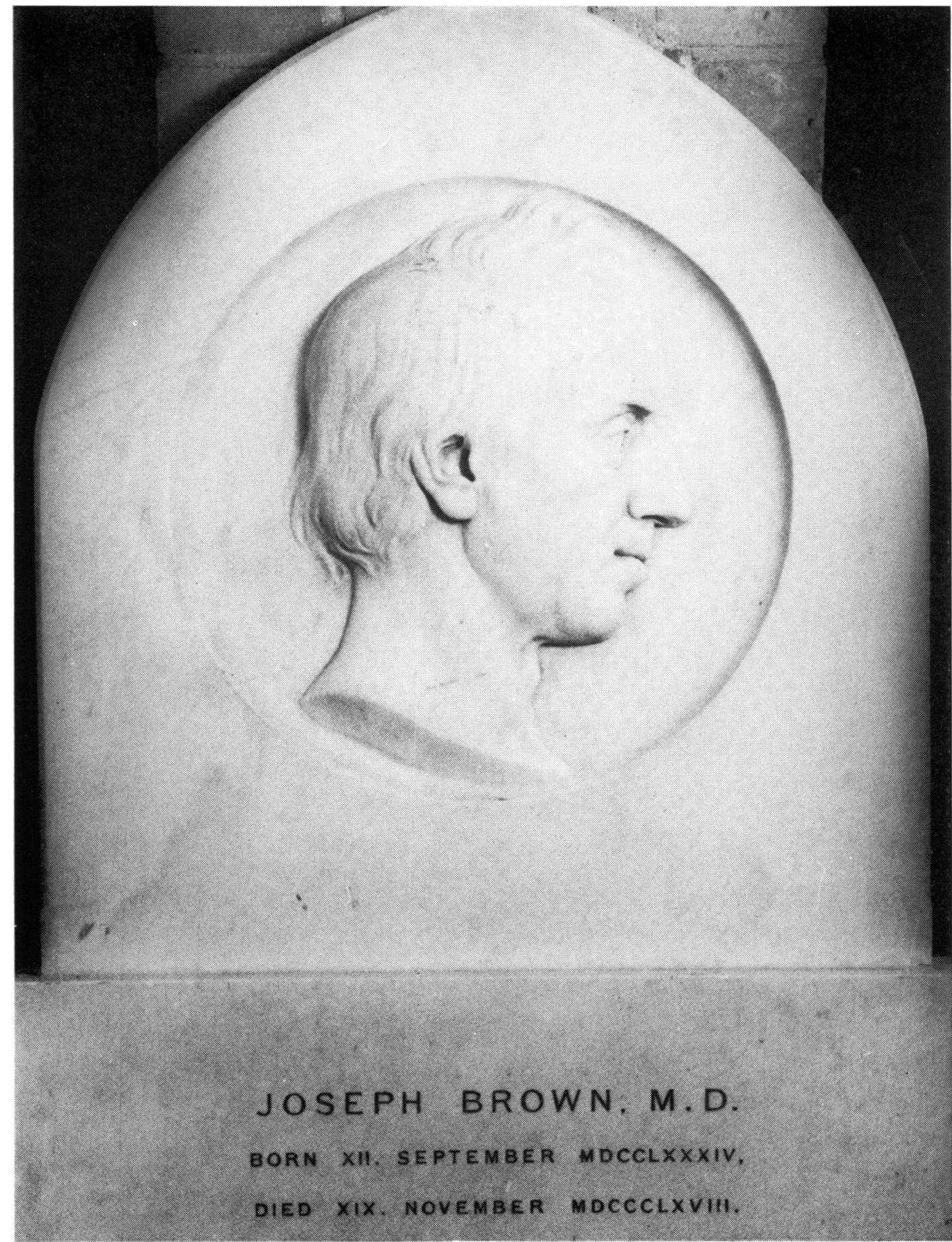

Figure 1.

Marble Bas-relief of Dr. Joseph Brown.

Formerly hung in the town library, at present in the Sunderland Museum. 


\section{Short Articles}

\section{REFERENCES}

1. Joseph Brown, Medical essays on fever, inflammation, rheumatism, diseases of the heart, etc., London, Longman Rees, 1828.

2. J. B. Herrick, $A$ short history of cardiology, Springfield, Charles C Thomas, 1942.

3. John Parkinson, 'Rheumatic fever and heart disease' [The Harveian Oration], Lancet, 1945, ii: :657-663.

4. J. B. Bouillaud, Traité clinique des maladies du coeur, Paris, J. B. Baillière, 1835.

5. J. B. Bouillaud, Nouvelles recherches sur le rhumatisme articulaire aigu en général et specialement sur la loi de coincidence de la péricardite et de l'endocardite avec cette maladie etc., Paris, J. B. Baillière, 1836.

6. James Hope, A treatise on the diseases of the heart and great vessels, London, Churchill, 1831.

7. Sir Neil Cantlie, A history of the Army Medical Department, Edinburgh, Livingstone, 1974 , vol. 1, p. 365.

8. William Munk, The roll of the Royal College of Physicians of London, London, Royal College of Physicians, 1878, vol. 3, p. 284.

9. R. J. H. Bertin, Traité des maladies du coeur et des gros vaisseaux, rédigé par J. Bouillaud, Paris, J. B. Baillière, 1824.

10. Parkinson, op. cit., note 3 above.

11. Joseph Brown, 'Obituary notice', Med. Times Gaz., 1868, 2: 683-684.

12. Joseph Brown, Memories of the past and thoughts on the present age, London, Longman, 1863.

\section{FURTHER BIBLIOGRAPHY}

W. Brockie, Sunderland notables, Sunderland, Hill, 1894, pp. 256-265.

Dictionary of national biography, London, Smith Elder, 1885-1900, vol. 3, pp. 21-22.

A. Peterkin and W. Johnston, Commissioned officers in the medical services of the British Army 1660-1690, (ed. by Sir R. Drew), London, Wellcome Historical Medical Library, 1968, vol. 1, p. 188.

W. Robinson, The story of the Royal Infirmary, Sunderland, Sunderland, Hills, 1934. 